\title{
HEC syndrome
}

INSERM

\section{Source}

INSERM. (1999). Orphanet: an online rare disease and orphan drug data base. HEC syndrome. ORPHA:2119

HEC syndrome is characterised by communicating hydrocephalus, endocardial fibroelastosis (EFE), and cong enital cataracts. It has been described in two children, both of whom died a few months after birth (the first as a result of a respiratory infection and the second due to cardiac complications). The aetiology of the syndrome is unknown but a viral or genetic origin has been proposed. 